\title{
Writing as Resistance: A Reading of Mohsin Hamid's Select Novels
}

\section{Rongina Narzary}

https://orcid.org/0000-0002-2637-1235

Arya Vidyapeeth College, Guwahati, Assam

\begin{abstract}
Mohsin Hamid, one of the powerful voices to emerge from Pakistan engages with themes that go beyond the partition of India and Pakistan in 1947 and portrays contemporary issues relevant to Pakistan. In the process, Hamid consciously performs the role of the mediator and attempts to explain his country to the readers. In his two novels, Moth Smoke and The Reluctant Fundamentalist Hamid not only represents modern-day Pakistan but also offer resistance to the association of Pakistan with terrorism thereby replicating the postcolonial tendency to "write back" and reclaim one's identity. Furthermore, he offers a nuanced understanding of the hostilities that prevail between India and Pakistan. Fictional representations of Islam and Muslim identities by writers of Pakistani origin have received increased attention, especially in the post 9/11 political climate with its attendant reductive representations of Islamic fundamentalism. The 'war on terror' which has had the effect of equating Islam and Muslims with terrorism has become a dominant political narrative in Europe and the US over the last decade. It is such diffused representation of Muslim identity which has evoked criticism in the 'orient' and Hamid shines bright in this regard.
\end{abstract}

Keywords: 9/11 Literature, Pakistan, Postcolonial writing, Resistance, Religious Fundamentalism, Islamophobia.

Farahnaz Ispahani refers to Pakistan as 'The Land of the Pure' in her book Purifying the Land of the Pure: Pakistan's Religious Minorities (2017), however, in the present times Pakistan has become synonymous with Islamic fundamentalism and terrorism in the global arena. Very few instances of positive happenings reach out to the global spectator from the nation which is preoccupied with battling political turmoil, corruption and terrorism. In the last few decades, Pakistan has been flayed for its dubious foreign policy-- which ultimately culminated in the 
dramatic killing of the 9/11 mastermind and the leader of the Al-Qaeda -Osama bin Laden- at Abbottabad in Pakistan leading to a strained Pak-US relation. Historically this association of Pakistan with Islamic fundamentalism can be traced to the regime of the military dictator General Zia who believed Islamization was the only way to safeguard the nation from separatist forces within. According to Shah et al:

The process of Islamization was firstly introduced in Pakistan by General Zia-ul-Haq who persistently focused on adopting and enforcing Islam in every sector and walk of life in Pakistan. Zia and his companions firstly decided that Islam was the chief uniting factor in the divided country of Pakistan (60).

General Zia perceived Pakistan to be an 'ideological state' and believed that only the 'spirit of Islam' could sustain Pakistan. Furthermore, when Russia invaded Afghanistan in the year 1979 the Taliban refugees crossed over to Pakistan and greatly influenced the common masses with their radical ideas. Assessing the significance of these circumstances Chopra and Chadda writes:

The new phase of Islamic resurgence has been spurred by the following events: Soviet presence in Afghanistan following the overthrow of the Daud regime and a large-scale exodus of conservative mullah Afghan refugees into Pakistan and Iran; the success of the Mujahedeen in ousting the Karmal regime gave a tremendous boost to the fundamentalist... Pakistan military regime's claims of introducing Islamic order, Nizame-Mustafa in the country...(15)

Such radical religious policies implemented by political leaders to consolidate their power have subsequently culminated in the alienation of the Pakistani population in the present times. The world at large lives in fear of the Islamic world -a fear which is founded on misconceptions and misrepresentations of the religion and its association with terrorism. This 
stereotyping of Muslim identity has resulted in unfounded hostilities against them especially in the western world and has given momentum to terrorist activities on a rebound. As such the desire to restore faith in the culturally rich Pakistani population around the world is one prominent feature of contemporary Pakistani writing in English.

In the last few years, a group of talented writers have emerged from this troubled land creating waves in the international arena taking Pakistani literature to heights it had not scaled in the past. Exploring myths and stereotypes in the west about Pakistan and Islam, they have carved a niche for themselves in the global literary spectrum. Prominent among them are Bina Shah, Kamila Shamsie, Uzma Aslam Khan, Mohammad Hanif and Sehba Sarwar to name a few, all of whom have proved to be authors extraordinary. Most of these Pakistani writers writing in English write about contemporary realities exploring the issue of identity for expatriates, religious fundamentalism and other social issues pertaining to Pakistani identity. In the Anglophone fiction by the younger generation of Pakistani writers, the focus is shifted from partition to other contemporary events and issues.

Mohsin Hamid, one of the emerging voices in the Pakistani literary world shatters cultural stereotypes in his widely acclaimed novels Moth Smoke and The Reluctant Fundamentalist. His first novel Moth Smoke, set in Lahore in the summer of 1998, captures the tensions between India and Pakistan. The novel may be considered as a multi-layered postmodern narrative exploring issues as diverse as politics, class division, corruption and women. The novel's anti-hero is Daru Shezad, a young banker who loses his job and drifts into the world of drug addiction, poverty, and criminality. Daru kills moths when he is bored. The bitter jealousies that develop between Daru and his former friend Ozi culminate in revenge. This episode carries an allegorical weight within the broader context of the nuclear rivalries between 
India and Pakistan. The extremes of wealth and poverty we encounter in the abrupt shifts between Daru's unlit room and the jet-set society which he flutters around echoes Pakistan's social divide as its economy begins to crumble. His second novel, The Reluctant Fundamentalist (2007) explores the fear and suspicion that followed the 9/11 terrorist attacks. Hamid is sensitive to the world around him and willingly shoulders the responsibility of revealing to the world the present state of Pakistani society, politics and the ills that hamper the growth of Pakistan. In this context Claudia Perner in her article titled Tracing the Fundamentalist in Mohsin Hamid's Moth Smoke and The Reluctant Fundamentalist writes:

For some time we have witnessed the emergence of a generation of "postcolonial" writers for whom (post)colonialism has become an increasingly distant family memory. They understandably find it rather tedious to be read first and foremost as representative of a certain cultural and national context. In contrast to this, Pakistani writer Mohsin Hamid appears to willingly accept the ambitious task of "explaining" his country to his readers. Meanwhile, it seems that at least Western audiences continue to be in desperate need of such explanation, given the limited knowledge about other parts of the world that prevails in the West. Pakistan is often perceived as merely one of those far-away places that serve as breeding grounds for extremism and violence. Hamid's acceptance of his position as a mediator-though clearly not the only significant feature of his work-is visible in most of his writing (23).

In the same article she further writes:

What unites both the novels (Moth Smoke \& The Reluctant Fundamentalist) is their interest in the complicated anatomy of contemporary Pakistan and in those feelings of resentment and deficiency that continue to grow among Hamid's countrymen (30). 
Such postcolonial concerns of unveiling Pakistan to the world project Hamid's writing as an instance of the 'east writing back' to assert one's rightful place in a world that is unapologetically hostile to his fellow men. In the context of representation of Pakistani women in the western world, Hamid attempts to shatter the negative image of Pakistani women as passive and insignificant by portraying urban women in his novels. He offers a glimpse of the changing face of Pakistani women illuminating and refuting at the same time the myth surrounding Pakistani women as victims of religious fundamentalism and patriarchy. In his debut novel Moth Smoke, Hamid has given counter-narratives and one of them is Mumtaz Kashmiri's, the U.S educated wife of Aurangzeb or Ozi as he is known to his friends. She feels trapped in her marriage on being coerced to experience motherhood and sacrifice her career contrary to her desire. She suffers neglect from her husband and seeks fulfilment in her husband's childhood friend Daru Shezad. A clandestine affair follows which proves disastrous for both. Subsequently, she becomes alienated and asserts her freedom and identity by refusing to succumb to the set roles of a mother, wife, or mistress. She finds solace in her creative work.

In his second novel The Reluctant Fundamentalist, Hamid portrays modern women who are professionals and not the typical burqah clad victimised Pakistani women, who are at the mercy of their male counterparts. However, what Hamid portrays in his novels is true regarding a small section of Pakistani women. Women at large continue to be exploited in Pakistan like any other developing country. Hamid illuminates and refutes the myth surrounding Pakistani women as suppressed and 'voiceless' by focusing on modern Pakistani women who rebel against the set rules of society. But to what extent these 'privileged' women are successful in asserting their identity and individuality is yet to be determined. 
Another significant aspect of Moth Smoke is that it projects a society divided into two groups; the rich run the corridors of power and the poor lead a miserable life. Chambers rightly observes that Hamid “in particular is interested in millennial Pakistan's voluptuary, ecstasytaking social whirl, as well as more familiar scenes of violence and stark class divisions" (117). The jet-set have access to a world where there is no scarcity of jobs, food or material goods and laws can be manipulated to accommodate their transgression whereas the poor languish in poverty. In Moth Smoke Daru struggles with his education whereas his friend and contemporary Ozi are sent to the US by his father-the frequently investigated former federal secretary Khurram Shah. In the days following Ozi's return to Pakistan, the socio-economic divide between Daru and Ozi widens; Daru is fired from his banking job and subsequently degenerates into the world of drugs and crime. On the other hand, the affluent Daru drives luxury cars and resides in a mansion and finally manages to escape punishment for drunken-driving and manslaughter by manipulating the law using money and influence. Interestingly the money which sustains the 'creamy layer' of Pakistani society flows from international sources. It is this very aspect of the Pakistani society which is at the receiving end of Hamid's satiric gaze. In this context Nayar's emphasis on neocolonialism as an important area of interest in Postcolonial discourse is most relevant:

Neocolonialism is the continuing economic exploitation of the Asian and African nationstates by the European and American powers. What is significant is that the former colonial masters are still in economic control over so-called 'free' former colonies. The colonies may not be 'colonies' in the strict sense of the term, but their dependence upon and exploitation by former masters continues. In most cases, neocolonialism is achieved not merely through state control by Euro- American powers, but by a nexus between the 
politician, the banker, the general, the Chief Executive Officers (CEOs). While physical force (military or police) may not be an immediate event in neocolonialism, trade sanctions by former colonial masters are invariably accompanied by the threat or eminence of military action against the' erring 'Asian/African nation-state (5-6).

Munawar Iqbal Ahmed analysing this aspect of the novel writes:

The satiric target in Moth Smoke is a neo-colonialism that represents economic and political bondage. The economy of Pakistan is controlled by multi-national corporations that provide local dictatorship to government ministers, their cronies and other capitalists. The education system is just a replica of the Macaulay model in which the rich and the poor, the ruling elite and the common masses, go to separate schools and universities. Moth Smoke presents, then, an indictment of 'development', multi-national corporations, international finance, and neo-colonial education (220).

Furthermore, the novel focuses on the souring relationship between India and Pakistan, the nuclear arms race and the subsequent economic sanctions which followed it. Moth Smoke is set in the 1990s when the two neighbouring countries were indulging in the nuclear arms race. In the novel both the rich and the poor celebrate the successful completion of the nuclear tests. People swarm the streets of Lahore celebrating this victorious moment firing Kalasnikhovs in the air and the jet-set partied behind high walls. As Daru comments:

The excited trrringing of the bicycle bells brings me to the gate, witness to the victory parade of a half a half-dozen gardeners, long shears tied to the backs of their Shorabs, pedaling triumphantly, wobbling, clapping as often as balance and courage would allow.

He is not untouched by the whole celebration: 
I feel something straighten my back, a strange excitement, the posture-correcting force of pride. Manucci looks up at me, his face sweaty, dirty, and grins. We shake hands like old comrades, two warriors home at last, and I am about to say something, to launch into a little self-congratulatory speech, when a sound interrupts the flow of my elation. From somewhere down the road we hear the first burst of celebratory gunfire, a hard-edged firecracker set to automatic, emptying of magazine into the sky (121).

Hamid critiques the arms race from the point of view of the non-elite; Murad Badshah, the rickshaw fleet owner worries about the effects the nuclear tests might have on the already frail economy and points out that "this nuclear race is no joke. People are in trouble" and the Sindhi cap, however, retaliates by saying that "the Christians have a bomb. The Jews have a bomb. The Hindus have a bomb ...Everyone has a bomb. And now the Muslims have a bomb. Why should we be the only ones without it?" (124). People are divided in their opinion regarding Pakistan going nuclear. Hamid condemns this meaningless competition between India and Pakistan and offers us a glimpse of how the whole episode affected the already frail Pakistani economy. In this context what S. Kumar writes his book India and Pakistan is relevant:

Traditionally, the history of Indo-Pakistan relations has been mainly a story of conflict and discord, mutual distrust and suspicion. It has resulted from several intricate factors like legacy, the difference in religion and race, conflicting national interests and ideologies, the power struggle between the two countries, the roles they have played in international politics and various territorial disputes including Kashmir. In other words, Indo -Pakistan relations have been influenced, perhaps bedeviled, by questions at issues going back to the pre-partition days, emerging from the partition and arising after partition. They were also influenced by external factors. The major factor, however, has 
been the perception of each other and themselves. Most of the problems had arisen out of the perpetual divergence (24).

Hamid portrays this very conflict through his writings and voices the Pakistani side of the story. Furthermore, The Reluctant Fundamentalist, Hamid's second novel can be seen as a reaction to the discourse of colonization from the Pakistani side. Hamid projects the changing dynamics of Pakistani identity in the western world and protests against the terrorist label ascribed to the Muslims post 9/11 attacks. The novel records the changing relationship between Pakistan and America post 9/11 attacks and offers a critique of the role played by America in international politics. Hamid's The Reluctant Fundamentalist is written in the form of a dramatic monologue, Changez, the protagonist of the novel indulges in a one-sided conversation with an American stranger. The narrative itself is suggestive of the mutual distrust and suspicion which exist between the East and West.

In the novel The Reluctant Fundamentalist, it is the attitude of the Americans which convert Changez into 'the reluctant fundamentalist' and not his religion. He becomes alienated from his second home (America) after he experiences racism post 9/11. He is also disgusted by the 'war on terror' waged in Afghanistan- a country that resembles his own. He resolves to no longer work for Underwood Samson and consolidate the American Empire.

Excuse Me, Sir, but may I be of assistance? Ah, I see I have alarmed you. Do not be frightened by my beard: I am a lover of America (1).

The opening lines of The Reluctant Fundamentalist showcase the mutual suspicion and mistrust which exists between the East and the West. Changez, a Princeton educated Pakistani eulogies about his stay in America to an unknown American. The novel opens on a mysterious note. We never come to know the real identity of the American. He might be a tourist or an 
undercover agent sent to kill the Pakistani. Both the individuals suspect one another thus reflecting the mistrust and suspicion which exist between the East and the West. Changez, the protagonist of the novel, indulges in an unsolicited monologue about his stay in America. To Changez, New York was a city of opportunity and success. In the beginning, he assimilated with the crowd; fell in love with an American girl Erica; and considered himself a New Yorker. On his visit home after a gap of many years, he was struck by the shabby condition of his house. But he had to face the reality after the 9/11 attacks on Pentagon and the Twin Towers. The incident itself pleased him in some strange manner:

I stared as one-and then the other-of the twin towers of New York's World Trade Center collapsed. And then I smiled. Yes, despicable as it may sound, my initial reaction was to be remarkably pleased (72).

Irfan Hussain's book Fatal Faultlines: Pakistan Islam and the West gives an insight into the connection between Muslim identity and religion. It helps one in deciphering Changez's reaction to the horrifying terrorist attack:

Faith is probably the most important element in a Muslim's identity-an idea quite alien to most westerners, who usually define themselves in terms other than purely religious ideas. If asked who they are, most Muslims believers would reply 'Muslims' before naming their nationality or ethnic group. This deep allegiance to their religious belief, combined with their concept of ummam, makes most Muslims react to the plight of their fellow believers with a sense of outrage and urgency not found among followers of other religions (10).

In the novel Changez explains his emotions in the following manner to the American stranger: 
But at that moment, my thoughts were not with victims of the attack-death on television moves me most when it is fictitious and happens to characters with whom I have built up relationships over multiple episodes-no, I was caught up in the symbolism of it all, the fact that someone so visibly brought America to her knees (73).

Changez becomes alienated from America because of the situation which followed the 9/11 attacks. He undergoes some sort of an identity crisis but later the Pakistani in him wins the battle and he embraces his ethnicity driven by the antagonistic attitude of the Americans and not because of his religion. After the 9/11 attacks overnight he was treated as an outsider in New York, and everyone looked upon him as their enemy. Further, he is moved by the concept of the janissaries- the Christian boys who were kidnapped by the Ottoman Turks and trained to consolidate their power. He views himself as "a modern-day janissary...a servant of the American empire" (120) at a time when it was invading his country. He identifies himself with them and defiantly resolves not to contribute to the growing economy of the West by toiling for Underwood Samson. He resigns from his elite job and returns to Pakistan and becomes a university lecturer. At one point in the novel Erica's father voices the general opinion in the West regarding Pakistan:

Economy's falling apart though, no? Corruption, dictatorship, the rich living like princes while everyone else suffers. Solid people, don't get me wrong. I like Pakistanis. But the elite has raped that place well and good, right? And fundamentalism. You guys have got some serious problems with fundamentalism (55).

The novel as a whole not only documents the hostile relationship between the East and the West Post 9/11 but also shatters certain preconceived notions regarding Pakistan. Hamid offers a vision of Pakistani modernity which breaks with the stereotype (that has prevailed since 9/11) of 
the region as fundamentally traditional, backwards-looking, essentially anti-modern. In both of his novels, Hamid offers altogether a different view of Pakistani women and society. Contrary to the stereotyped image of Pakistani women as weak and subdued, Hamid portrays independent women who are not afraid to chase their dreams. In the context of religion, Hamid challenges the association of Islam with terrorism and further exposes various aspects of America's 'war on terror.' Unveiling the intricate power nexus between the capitalist class of the Pakistani society and the colonial powers in a postcolonial set-up he offers a critique of neocolonialism which operates in $21^{\text {st }}$ century Pakistan. The economic sanctions accorded to the erring nation envelope a threat of armed attack and are portrayed as instances exerting control over the erstwhile colonial nations. In The Reluctant Fundamentalist too Hamid projects the souring relationship between India and Pakistan. The attack on the Indian Parliament by suspected Pakistani terrorists had further deteriorated the Indo-Pakistan relation. Changez, the protagonist, returns home because of the imminent war between India and Pakistan. He also worries about the growing proximity between India and America. Changez the protagonist of the novel is apprehensive about Pakistan's imminent war with India. On his visit back home post 9/11 the conversation at the banquet which was held in his honour centred around Pakistan's conflict with India. As Changez recounts:

But that night a family banquet was held in my honor, and there the conflict with India dominated conversation. Opinion was divided as to whether the men who had attacked the Indian Parliament had anything to do with Pakistan, but there was unanimity in the belief that India would do all it could to harm us and that despite the assistance we had given America in Afghanistan, America would not fight on our side (126-27). 
Hamid deftly captures the exact emotions of his fellow countrymen on a very sensitive issue and accurately portrays the present-day Indo-Pakistan relation. He offers a critique of the mindless nuclear race between the two nations in his novels and represents it as a self-destructive phenomenon. Based on the exploration of the various themes represented in the writings of Hamid it can be asserted that he explores contemporary issues in relation to Pakistan going beyond the theme of partition as represented in Pakistani writings in English in the years following the Independence. In Moth Smoke the Indo-Pak relation and their dissention regarding Kashmir come under the scanner. The corruption infested socio-economic condition of the once colonized Pakistani society is realistically portrayed and critiqued; so is the cultural baggage left behind by the erstwhile British rulers. In this context Ahmed writes:

Corruption and governance go hand in hand in the developing countries where the democratic process is often tainted by political inheritance, speed money, feudalism and the omnipresent intervention of neo-imperialist powers that support the corrupt(especially) military regimes. The process becomes more painful when a society is trying to develop in the face of rising security issues due to which it is profiled as 'highrisk investment zones.' The economic package comes with a lot of political strings, along with cultural baggage (220).

Mohsin Hamid represents the adverse impact of neocolonialism, the nuclear test and also the radical Islamization of the Pakistani society in the times of General Zia military regime in the novel. Furthermore, the novel also critiques the rapid polarization of the Pakistani populationbased on socio-economic factors. One of the main issues pertaining to contemporary issues as represented in the novel is that of women-Hamid refutes the passive image of Pakistani women as confined to the domestic space by unapologetically portraying a US-educated and sexually 
active Mumtaz who though temporarily confined to the role of a mother and a wife emerges as an independent woman in pursuit of her dreams. Another interesting aspect of the novel is the portrayal of Lahore. According to Ahmed, the city of Lahore emerges as one of the heroes of the novel. He writes:

With unscheduled load-shedding, uneven narrow roads, streets occupied by the criminals and terrorists, air full of gun-powder and tear gas by the police, and the absence of any basic civic amenities, the survival of the city is no less than heroic. The heat, dust, stink, noise and congestion make it one of the most uncontrolled places of the world (242).

Hamid portrays a city divided on socio-economic lines and infested by terrorism and corruption. Lahore is depicted as a difficult place for a person hailing from the lower rung of the society; jobs are scarce and connections prevail over the quality of the candidate in respect of getting employment. Amidst the chaos of the city dwell prostitutes like Dilaram who are victims of the feudal set-up. Mumtaz however, has access to things that are considered to be taboo for other women belonging to the same self-righteous Pakistani society—she drinks, smokes joint and indulges in an extramarital affair with her husband's childhood friend Daru. Hamid represents the various dimensions of Pakistani society to the world at large in a predetermined attempt to explain his country to the world and bridge between Pakistan and the West.

Furthermore, Hamid's experience of living in America and other parts of the world enables him to capture and represent the hostility experienced by Muslims in general in the western world post 9/11. Hamid responds to stereotypical representations of Pakistanis as terrorists by challenging and refuting the association of Islam with terrorism by subtly asserting in his novel The Reluctant Fundamentalist that it is the attitude of the western superpowers which induces a talented individual pursuing the American Dream to embrace his ethnic identity. 
Instances of racial discrimination also form the background of the novel. Changez takes pride in his culture and attempts to gain the trust of the mysterious American tourist/agent by drawing his attention to the positive aspects of his country be it food or women and by proclaiming himself to be a 'lover of America.' The Pak-US relation as such forms the centre of the novel and India's relation with America also pre-figures in the background. Hamid examines the role of America in international politics and critiques the violence perpetrated by the European superpowers under the pretext of waging a 'war on terror.' American capitalism is also at the receiving end of Hamid's close look at the western world. One important thread in his writing is his intimate representation of the rise of Islamic fundamentalism and also the subsequent association of Islam with terrorism. Hamid underscores that such a stereotypical representation of Pakistani men as terrorists is erroneous and prejudiced. He makes an effort to redeem the image of his fellow in the eyes of the western world. His writings as such provoke the western world to evaluate their stand in relation to Pakistan and Islam. Furthermore, Hamid's Pakistan can be seen as a metaphor of any postcolonial nation reeling under the exploits of neocolonialism; in this context, the trade sanctions awarded to the erring nation becomes a means of coercing the nation in question to perform the will of the economic superpowers. The rise of terrorism and the rampant corruption which prevail in Pakistan are closely scrutinized and the role of America is surveyed from all perspectives. In the novel The Reluctant Fundamentalist Changez views Pakistan both as an outsider and as a denizen of the troubled land; Changez's return to Pakistan in certain ways suggests the dubious role performed by America in its relation with both Pakistan and India. Hamid by focusing on issues pertaining to the present times performs the role of witness concerning the violence perpetrated by insurgent groups under the veneer of religion and attempts to overcome the stigma of the terrorist label attributed to Pakistanis by the western 
world. Hamid falls back on history to foreground the circumstances leading to the emergence of Islamic fundamentalism in Pakistan; such an act brings under the scanner the presence of erstwhile Soviet Russia in Afghanistan during the Cold War and the subsequent response of the Americans by asserting its influence in the Pakistani soil. What Hamid attempts to communicate is the message that America is the victim of its own devious political and economic policies. As such by exploring contemporary issues in his two novels Hamid offers resistance to the misconceptions which prevail in the west about Pakistan, Islam and the East. Hamid's creative engagement with contemporary issues in relation to Pakistan enables him to be an agent of change and marks the dawn of a new era in Pakistani Writing in English. Hamid's Moth Smoke and The Reluctant Fundamentalist refute stereotypical representation of Pakistani identity, culture and religion and offer resistance to the Western idea about Pakistan. Hamid's main concerns are Islamic fundamentalism, the image of Pakistani women and the corruption infested Pakistani society. Hamid's factual portrayal of contemporary Pakistani society proves to be an instance of the 'east writing back' challenging the prevalent notions of the Islamic state as the breeding ground of terrorism; women as passive and constrained by religion and the patriarchal set-up of the Pakistani society. Considering all these visible postcolonial concerns in his writings-Hamid's role as a mediator between the East and the West cannot be undermined.

\section{Works Cited}

Ahmed, Munawar Iqbal: Post-Independence/Post-colonial Pakistani Fiction in English: A SocioPolitical Study with Focus on Twilight in Delhi, The Murder of Aziz, Khan, Ice-CandyMan and Moth Smoke. PhD Dissertation, National University of Modern Languages, 2009. http://prr.hec.gov.pk/thesis/693S.pdf 
Chopra, Surendra\&Chadda, Kusum Lata. Islamic Fundamentalism, Pakistan and the Muslim World. Kanishka Publishers, 2009

Chambers, Claire Gail. "Lahore Lahore Hai: Bapsi Sidhwa and Mohsin Hamid's City Fictions." Chakraborty, Madhurima and Al-Wazedi, Umme, (eds.) Postcolonial Urban Outcasts. Routledge, 2016, pp. 113-130.

Hamid, Mohsin. Moth Smoke. Penguin Books, 2000.

---. The Reluctant Fundamentalist. Penguin Books, 2007.

Husain, Irfan. Fatal Faultines: Pakistan, Islam and the West. Harpercollins, 2012.

Ispahani, Farahanaz. Purifying the Land of the Pure: A History of Pakistan's Religious Minorities. Oxford University Press, 2017

Kumar, S. India and Pakistan. Anmol Publications Limited, 2006

Nayar, Pramod. K. Postcolonial Literature: An Introduction. Pearson Longman, 2008

Perner, Claudia. "Tracing the Fundamentalist in Mohsin Hamid's Moth Smoke and The Reluctant Fundamentalist.”Ariel: A Review of International English Literature, vol.41, no. 3-4, 2011, pp. 23-31. https://journalhosting.ucalgary.ca/index.php/ariel/article/view/35084/28975

Shah, Ali Shan, Muhammad Waris \& Abdul Basit "Islamization in Pakistan: A Critical Analysis of Zia's Regime" Global Regional Review (GRR), vol. I, no. I, 2016, pp. 260-270 http://dx.doi.org/10.31703/grr.2016(I-I).20

\section{Bionote:}

Rongina Narzary teaches English Literature at Arya Vidyapeeth College, Guwahati. Her area of research is Transgender Studies. She can be reached at arongina.narzary@gmail.com

ORCID ID: https://orcid.org/0000-0002-2637-1235 


\section{Open Access:}

This article is distributed under the terms of the Attribution-NonCommercial 4.0 International (CC BY-NC 4.0) (https://creativecommons.org/licenses/by/4.0/) which permits any use, reproduction and distribution of the work without further permission provided the original work is attributed as specified on the Transcript: An e-Journal of Literary and Cultural Studies. For more information log on to http://thetranscript.in/

\section{Conflict of Interest Declaration:}

The author declared no potential conflicts of interest about the research, authorship and publication of this article.

(C) Author 